\title{
Climate justice and home-buyout programs: renters as a forgotten population in managed retreat actions
}

\author{
Leah A. Dundon ${ }^{1}$ (D) - Janey S. Camp ${ }^{2}$ (D) \\ Accepted: 22 April 2021 / Published online: 4 May 2021 \\ (C) AESS 2021Abstract
}

For most Americans, the value of their home represents the largest portion of their total wealth; accordingly, homeowners even in very poor areas can obtain some benefit from a home-buyout program as a means to move away from risk and begin again. Renters, however, are an overlooked population during implementation of post-disaster retreat programs that predominantly focus on homeownership. Racism is a substantial factor in homeownership disparities between black and white Americans that can be traced to the post World War II GI Bill — a law that delivered to returning veterans federally-backed home mortgage loans, loans that were largely denied to returning black soldiers. These inequities have not been overcome, leaving minority renters as some of the most vulnerable populations after a disaster. Indeed, some renters may be substantially worse off after a buy-out program is implemented in an area. Renters represent an atypical "trapped" population when it comes to relocation programs because they may be economically forced to move to even more climate vulnerable housing. This paper will explore postimplementation impact on renters of home buy-out and similar retreat programs. We will examine the factors that contribute to this cycle of failed re-location efforts for this sub-group such as the lack of retreat policies aimed at assisting low-income renters, lack or limitations of home or rental insurance, the absence of "duty to warn" obligations from landlords to inform renters of repeated flooding risks at the property, and market failure to encompass climate risks in rental pricing.

Keywords Managed retreat $\cdot$ Home buy-out $\cdot$ Renters $\cdot$ Floods $\cdot$ Disaster insurance $\cdot$ Resilience

\section{Introduction}

For several generations, the home has represented the single most important and most valuable asset that most Americans will ever own, comprising a substantial part, if not the vast majority, of their lifetime wealth. Homeownership also is responsible for inter-generational wealth when that substantial asset is passed down to the next generation. In addition to wealth, homeownership provides some relative security in

Leah A. Dundon

Leah.a.dundon@vanderbilt.edu

Janey S. Camp

janey.camp@vanderbilt.edu

1 Civil and Environmental Engineering, Vanderbilt Climate Change Initiative, Vanderbilt University, 2301 Vanderbilt Place, VU Station B \#351831, Nashville, TN 37235-1831, USA

2 Department of Civil and Environmental Engineering, Vanderbilt Engineering Center for Transportation and Operational Resiliency (VECTOR), Vanderbilt University, 2301 Vanderbilt Place, VU Station B \#351831, Nashville, TN 37235-1831, USA the context of climate change that is not available to those that do not own a home. For example, a home is a valuable asset against which one can borrow to make oneself more resilient to climate impacts, but it also is an asset that is necessary to qualify for certain disaster relief or mitigation programs. Renters are often a forgotten population in this mix of resilience and relief programs, and they too often are also people of color, raising environmental justice - or "climate justice" concerns, a term often used when referring to the disparate negative impacts that minority and vulnerable groups (and countries) often face because of climate change.

Existing research shows that white people in the USA are more likely to own their homes than other minority groups (Kochhar et al. 2011). In addition, homes owned in African American and Hispanic communities tend to represent a disproportionately larger part of the household total wealth than in the white community (ibid), meaning that these communities have fewer liquid assets to turn to in the event of a natural disaster even when they do own their home. Accordingly, when a disaster strikes, if the house is impacted, there is a larger negative impact to that household's total wealth because the house makes up a disproportionately larger share of that total wealth. 
This disparity in homeownership rates between white Americans and minority Americans is not an accident, and although this paper cannot and does not intend to capture the entirety of this important subject, this history is a critical component of the environmental justice issues faced by minority communities today. Much of the economic inequality in regard to homeownership that exists today - as well as the segregation between people of color (especially AfricanAmericans) and white Americans with respect to living areas - can be directly traced to slavery and the long succession of deliberately racist laws and policies that followed after. Rothstein (2017) observed that not long after the end of the Civil War, the South adopted segregation laws (Jim Crow laws), and segregationist laws and policies soon spread to many other parts of the country where formerly enslaved people had moved after the Civil War. Where small towns often expelled black populations altogether, larger cities adopted overtly racist ordinances, such as prohibiting African-Americans from purchasing homes in white areas (Rothstein 2017). Throughout the early 1900s, zoning and land use laws were similarly used to advantage white people and to disadvantage black people with respect to land and homeownership, such as by allowing development of industrial and other commercial uses (such as bars, prostitution, or liquor stores) in an area if African Americans began to move into the area, contributing to the destruction of neighborhoods and the creation of slums (Rothstein 2017).

Rothstein (2017) details the effort by the federal government near the end of World War I to entice white Americans to build and own single-family homes as a stalwart against communism, but also to avoid racial strife, with entrenched policies assuring that only white people would likely end up owning those homes. Despite federal government encouragement, even very few white people owned homes before World War II. At that time, homeownership was the province only of the very rich, largely because it typically required large $(50 \%$ or more) down payments to obtain a mortgage and very short repayment periods (Murray 2008; Rothstein 2017). President Franklin D. Roosevelt signed both the National Housing Act in 1934 as part of the New Deal legislation, ${ }^{1}$ and the Servicemen's Readjustment Act of 1944 (known as the "G.I. Bill of Rights"2); together, these laws radically changed access to homeownership in America. Eligible veterans could then borrow money with little or no down payment to purchase land (such as farms), houses, farming equipment, and

\footnotetext{
${ }^{1}$ The citation "12 U.S.C. § 1701, et seq." has been changed to "12 U.S.C. § 1701, et seq., n.d." to match the author name/date in the reference list. Please check if the change is fine in this occurrence and modify the subsequent occurrences, if necessary.12 U.S.C. § 1701, et seq. n.d.

2 The citation "38 U.S.C. § 3701 et seq" has been changed to "38 U.S.C. § 3701 et seq., n.d." to match the author name/date in the reference list. Please check if the change is fine in this occurrence and modify the subsequent occurrences, if necessary.38 U.S.C. $§ 3701$ et seq. n.d. (current provisions)
}

more, with 30-year repayment periods. As Murray (2008) observed, "[n]early five million veterans bought homes under the G.I. Bill, amounting to almost half of the new homes constructed in the United States in the decade following World War II." The G.I. bill also provided these returning veterans free "education or training" which included up to 4 years of college or other types of vocational training (Blakemore 2019), further increasing their ability to obtain wealth and stability that would then be passed down to future generations. The landscape of America was truly transformed by these laws, a middle class was firmly established, and the security of homeownership was felt my millions of Americans.

However, millions of other Americans-largely Americans of color-were excluded from this huge homeownership, education, and training boom that is the direct origin of the wealth and security that many white families enjoy today. The federal G.I. Bill did not expressly discriminate on the basis of race, but because of pressure from Southern lawmakers whose votes were needed to enact the federal statute, the law allowed states substantial discretion to implement its provisions (Blakemore 2019). As a result, overtly racist laws and polices (not only in the American South) denied to black Americans (and other minorities (Ramos 1998)) the promise of homeownership, education, and skills that these federal laws provided to white Americans. Today's urban segregation and the vast disparities in personal wealth, family wealth, and educational and professional attainment are the lingering products of decades of racist laws, regulations, and policies devised and implemented at all levels of government. Data from 2014 showed that at that time, $72 \%$ of white Americans owned their home, while only $43 \%$ of black Americans owned their home (Traub et al. 2015). Climate change is only compounding the challenges of being poor and marginalized in America.

Billion-dollar disaster events - that is, extreme weather events with losses that exceed \$1 billion each-have been steadily increasing in the USA (Fig. 1). While there is a strong consensus that some extreme weather events have increased as a result of climate change (USGCRP 2018), the authors caution that this also reflects the increasing impacts to infrastructure systems and people (i.e., more people in an area results in more stuff being damaged when a disaster occurs). Additionally, as population grows and disparities continue, more vulnerable populations are being exposed at higher rates and severity with climatic changes.

Accordingly, there is an increasing understanding among researchers, local governments, and others that in some areas of the country, it no longer makes sense to rebuild in the same place or in the same way following a devastating extreme weather disaster event. Accordingly, programs to effect "managed retreat," from vulnerable areas (whether moving people, infrastructure, or both), are just beginning to emerge in the 
Fig. 1 Frequency of billion-dollar disaster events. Source: NOAA National Centers for Environmental Information

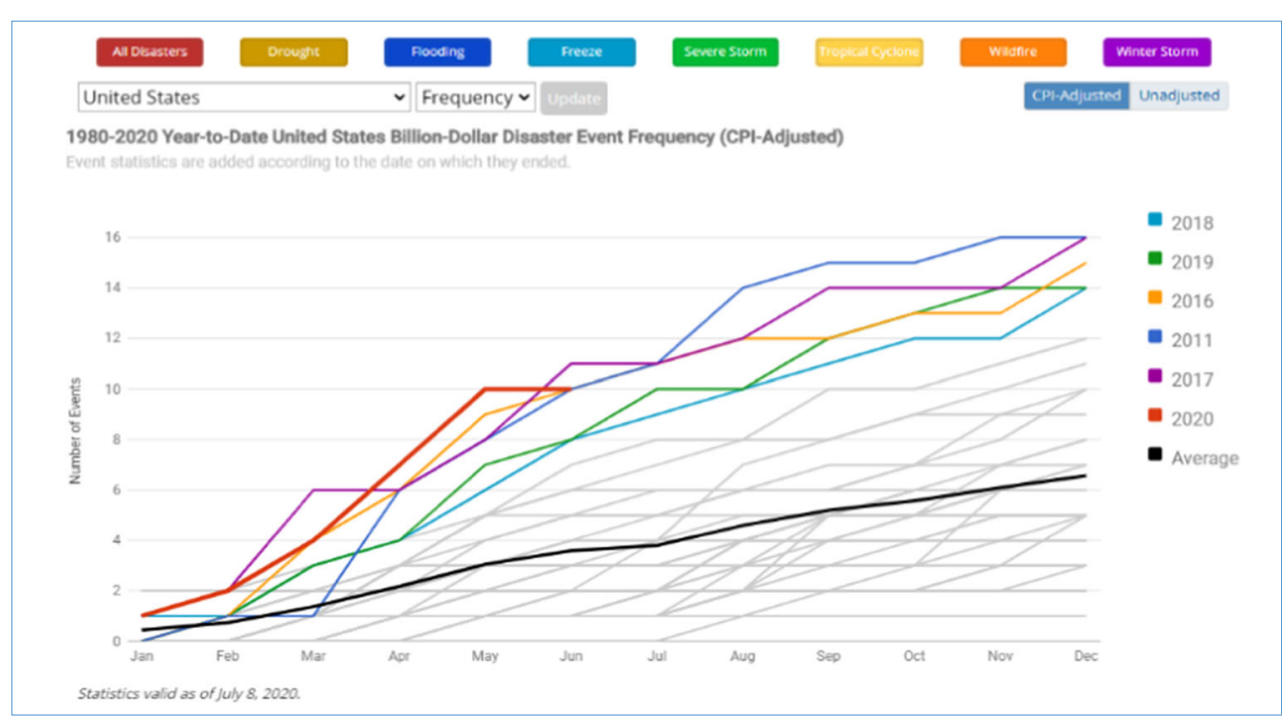

USA, as the corresponding research also continues to grow (Mach et al. 2019). Indeed, in the USA, the primary method of "managed retreat" is implementation of existing home buyout programs (Siders 2019). These programs have been in use in the USA for upwards of three decades or more, but many communities have only more recently begun to see residents take advantage of them, in part because of increasing disaster impacts, and because of increased awareness of and funding for programs focused on reducing risks through purchase and removal of homes following disasters.

In a home buy-out program, funds allow local governments to purchase private (typically residential, single family homes) property and reclaim the land, often for use as a natural greenspace (i.e., parks and greenways) that can then absorb/ mitigate flood waters, increasing the area's resilience by protecting nearby infrastructure (Nelson and Camp 2020). Often, the funding for these programs is a compilation of federal, state, and local funds with the federal contribution covering the majority of the costs (FEMA n.d.-d). These programs and their relationship to renters are discussed in the "Home buy-out programs and renters" section.

\section{Climate justice: the special case of renters}

While there are many reasons affluent people may choose to be renters rather than homeowners (for example, youth, temporary job locations, personal preference, and ownership availability in expensive urban areas), low income has been documented as a primary reason to rent. Burby et al. (2003) found that low-income households make up two-thirds of the entire renting population in the USA. Furthermore, in a study of 51 communities in Nebraska, Paine (2017) found that renters made up over $50 \%$ of properties. Similar results have been found for other communities like King County, WA, where a look at environmental justice revealed that the majority of the renters in the floodplain were non-white (Paine 2019).

There is a dearth of peer-reviewed academic research or reviews on the climate justice implications of being a tenant, especially in more climate vulnerable areas. What does exist in the literature is primarily focused on a few specific events/ locations such as Hurricane Katrina's impacts to citizens of New Orleans, and the work is not centrally focused on the plight of renters (Fussell 2015; Fussell et al. 2010; Sastry 2009). However, the vulnerability of renters has been increasingly covered in the press (most often post-disaster) and researched by non-governmental organizations (NGOs), especially those groups in community support positions or those that provide knowledge to local governments or law-makers to address many of the inequities renters face (Ahmed 2019; AP 2006; Hammack 2019; Weil 2009). This type of work (for example, MDC n.d.; Ahmed 2019) has identified a myriad of particular inequities uniquely faced by renters that contribute to their increased vulnerability. Table 1 describes these primary Renters' Climate Inequities ( $\mathrm{RCI})^{3}$ that the authors have identified from a review of the literature, their own work, and personal conversations with flood mitigation and other adaptation professionals in high-risk areas.

One indicator of the lack of post-disaster support for renters is the level of aid going to renters in comparison to homeowners for specific historic events. Using both disaster

\footnotetext{
${ }^{3}$ The authors have coined the phrase Renters' Climate Inequities (RCI) to encompass the social, environmental, and economic justice considerations that renters face when it comes to climate change impacts; however, we note that there is a need for additional vocabulary to be developed that directly addresses the plight of the rental population faced with climate change impacts. The literature reveals that renters are an under-studied (and largely overlooked) population with respect to climate impacts, and development of appropriate terminology could serve to focus additional research on this group.
} 
Table 1 Renters' climate inequities

Renters' climate inequities

Less preparedness before a disaster event (MDC n.d.).

Co-vulnerabilities

Lack of knowledge of area risk

Lack of funding or intervention programs directly (and primarily) targeting the tenant population from immediate neighbor networks
Description

Renters often have little or no incentive, or authority, to invest in improvements to a rental home that will reduce the potential impacts of an event such as a flood. Additionally, the 2017 American Housing Survey found renters to be less prepared for emergencies (including evacuations) with only $58 \%$ of renters having access to $\$ 2000$ for an emergency compared to $85 \%$ of homeowners having that cash access (FEMA n.d.-c).

Renting households are more likely to be facing other financial, family, or professional challenges that use up limited resources. In fact, at least $46 \%$ of renters spend $30 \%$ or more of their income on rent and this percentage is even higher in high-risk areas like California and Florida (Insurance Information Institute 2020). In the 2018 US Department of Housing and Urban Development American Housing Survey, it was estimated that "renters are three times more likely [than homeowners] to need financial assistance to evacuate during a major disaster" (US Census Bureau 2018). Rental housing may also be old or of low quality in certain areas, making the structure itself more vulnerable to an extreme weather event. And, in some areas, rental housing is more likely to be in closer proximity to industrial or manufacturing facilities, putting them at greater risk if an extreme weather event causes an accident at such a facility (MDC n.d.). Additionally, for immigrant and other vulnerable populations in rental housing, concerns about legal status or language barriers may prevent individuals from obtaining appropriate insurance or assistance.

FEMA floodmaps are used by mortgage lenders, insurance companies, and builders, so homeowners are often well aware if their property is located in a high-risk area, but tenants are often not aware of flood risks, or of potential support available if their home is destroyed or damaged in an extreme weather event. An example of this can be seen with the Willow River apartment complex in Salem, VA, where an apartment complex with 300 units has suffered repeated flood damage dating to 1977 but continued to rebuild with federal insurance proceeds, with buildings repaired and then new renters move in, presumably unaware of the risks (Hammack 2019).

Additionally, outreach and educational materials that may be mailed out to those in high flood-risk areas by local authorities typically go to the homeowner's address using parcel or tax data as opposed to going to the residents through a door-to-door effort, so the tenant may never receive such information. There is also a significant lack of requirements or enforcement by local authorities ensuring the right to information and disclosure of flood risks be passed from the owner to the tenants. Some localities do have flood disclosure rules, and these vary significantly across jurisdictions. As an example, in Texas, landlords are not required to disclose to their tenants that the residence has flooded in the past (Rice 2019). Where disclosure rules do exist, those rules often do not guarantee that renters are fully informed due to confounding factors such as language barriers or complex relationships (that can involve power disparities) between the owner and tenants. Additionally, repetitive loss data is very difficult to obtain from FEMA (considered confidential information) should someone try to understand a property's history of flooding independently (FEMA 2019).

Most homeowners will have homeowners insurance, or a mortgage which requires such insurance. Depending on the location and proximity to floodways and floodplains of the property, homeowners may also be required to have insurance through the NFIP. In the 2017 American Housing Survey, not a single renter responded as having flood insurance (US Census Bureau 2018). Many renters are not aware of what types of flood of disaster insurance may be available to them, or if available, it may not be affordable.

Additionally, renters may not be able to afford the premiums associated with renters' insurance or flood insurance even if they are aware of the risks. Renters insurance also will often only cover the contents of the dwelling and neither that nor flood insurance will reimburse tenants for temporary housing, relocation costs, and other expenses incurred immediately following an event (FEMA 2020b).

Rental turnover may be high, resulting in reduced support

Renters in more transient neighborhoods may not have the established relationships with neighbors that can serve as a lifeline in a disaster. Even seemingly simple acts such as knowing a home are occupied and checking on a neighbor during or immediately following a disaster may be less likely without knowledge or personal connection to nearby tenants (MDC n.d.).

Community development organizations and federal and state investments, even when focused on affordable housing, tend to preferentially favor homeowners (Ahmed 2019). Even if these programs are successful in moving some renters into homeownership, the 
Table 1 (continued)

Renters' climate inequities

$\longrightarrow$

Post-disaster impacts are compounded by the above factors P
Description

remaining tenants are overlooked. As just one example, in November 2018, the US Department of Housing and Urban Development allocated more than $\$ 5$ billion in initial assistance to Texas after Hurricane Harvey. $\$ 1.1$ billion of that was allocated to a homeowner assistance program, $\$ 275$ million for home-buyouts, $\$ 100$ million for reimbursements to homeowners for certain direct post-disaster expenses, and $\$ 250$ million - only $5 \%$ of the total award — focused on affordable rental properties (US HUD 2018). As another example, Washington et al. (2006) documented huge disparities between the funding provided by the federal government that supports homeownership and community development programs, and those that support low income rental housingof an $\$ 11.5$ billion grant in Louisiana, only $\$ 920$ million was allocated to the latter.

Post-disaster risks that are disproportionally borne by renters include the following: the loss of the home entirely if landlords use the "opportunity" to sell or upgrade the property; no or little immediate financial relief aid; loss of rental housing stock causing rental prices to increase; or lack of replacement rental housing in the immediate vicinity which could result in renters having to relocate farther away from work/school or out of the area completely (MDC n.d.); additional stress that can compound health issues which can result in medical bills or loss of income from missed work (Ahmed 2019). These types of post-disaster impacts can lead to the renter population falling even further behind their homeowner counterparts, and because of the existing disparity in homeownership rates between white and non-white people, racial wealth gaps may correspondingly increase in a particular area after a disaster. Additionally, local or state laws may put renters in even worse situations during or following a flood event. For example, in Texas, the law forbids renters from withholding rent even if the dwelling is not habitable (Miller 2017; Tex. Rev. Civ. Stat. Ann. § 92.058); thus, renters may still be required to pay rent while being displaced and having to pay for other housing accommodations while the property is flooded or under repairs. record number data and FEMA Individual Assistance Program Data, which includes the Individuals and Households Program (IHP) and the Housing Assistance (HA) and Other Needs Assistance (ONA) programs, for both homeowners and renters ${ }^{4}$, a significantly smaller percentage of individual assistance funding goes to renters. This may be due to many factors including renters lack of knowledge of how to apply for assistance, social or cultural barriers such as those faced by undocumented immigrants that are fearful of government authorities, or the fact that repairs to building structures (homeowner assistance) are typically more costly than replacement of the contents (which is the assistance that renters qualify for). In Table 2, we compare five events in recent US history and the amount of individual assistance for the two groups. As shown in Table 2, the amount of total assistance granted to homeowners is much higher than to renters, as would be expected due to the cost of structure repair or replacement. Moreover, the rental amount column represents FEMA assistance for temporary housing, which is only available in presidentially declared disaster areas. The total dollars flowing to homeowners in that category is much

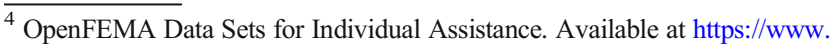
fema.gov/about/openfema/data-sets. Neither FEMA nor the Federal Government vouch for the data or analyses derived from these data after the data have been retrieved from the Agency's website(s) or Data.gov.
}

higher than to renters for all events with the exception of one event, the Salem Virginia flooding in 2004. As noted, there is at least one very large apartment complex that has had extensive and repeated flood damage (Hammack 2019), which may have contributed to the large rental amount assistance in that case. Interestingly, the amount of assistance per valid registrant for rental assistance is at least 1.4 times higher for renters than for homeowners (with the exception of Hurricane Harvey), potentially indicating that the homeowner's need for temporary housing is shorter or less significant than that of renters following the events considered here. It should be noted, however, that the repair and replacement amounts for assistance to homeowners would also include funds to owners of rental properties to restore dwellings to habitability.

Renters often also face substantial legal and policy barriers even before they sign a lease agreement that may contribute to a more vulnerable position when extreme weather strikes (Superstorm Research Lab (SRL 2013). For example, tenants are often required to sign what are known as "adhesion contracts." Essentially, the landlord requires the tenant to sign the lease "as is" (having been drafted by the landlord or his/her counsel, who typically holds superior bargaining power and greater knowledge about the property, and with provisions that tend to favor the landlord), or find another home to 


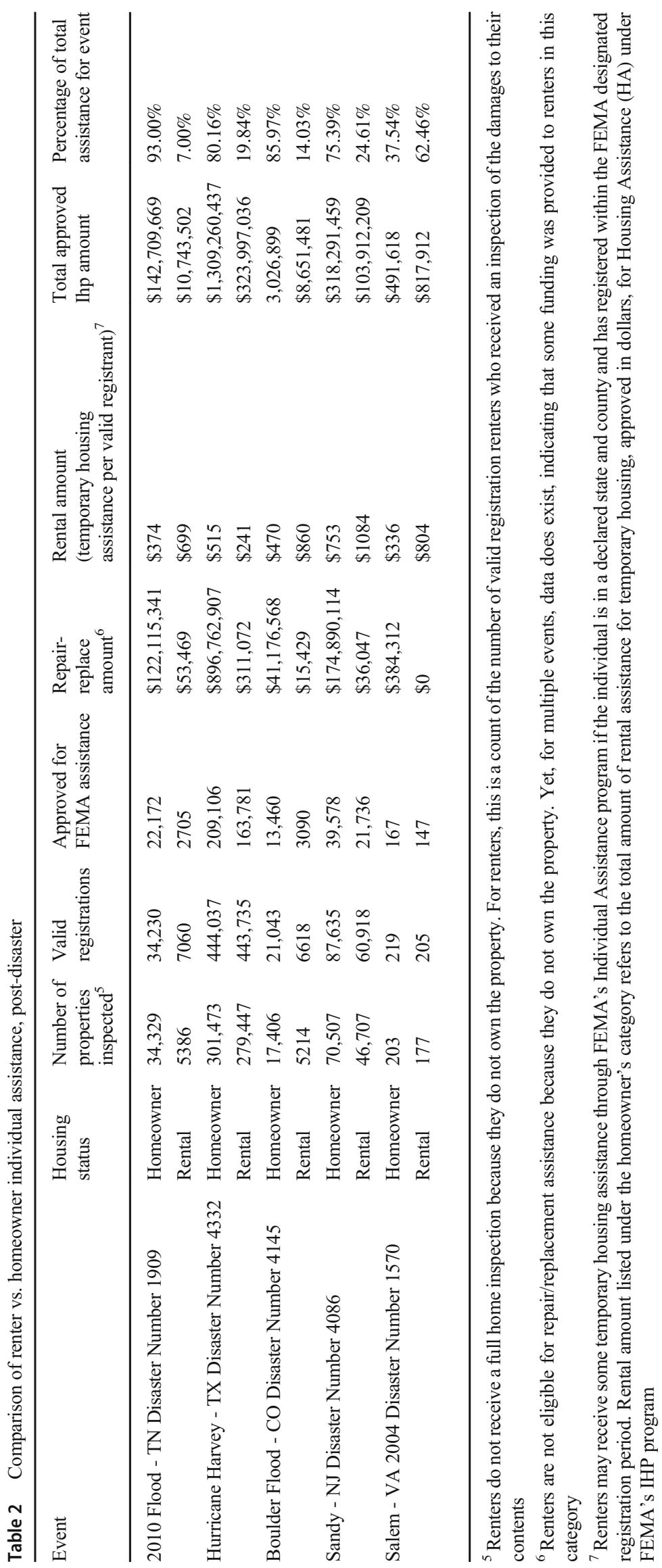


rent - there is no room for negotiation of even the most minor provisions. While there has long been controversy regarding the enforceability of these types of agreements, the trend is to view them as valid, enforceable contracts absent truly unconscionable terms (Tutt 2013).

The burdens of historical housing policies also created disadvantaged minority renters while their white counterparts became homeowners. Implementation of the federal housing laws noted above included "red-lining," the express drawing of boundaries around geographic areas of city, typically with predominantly black or Latino residents, considered at high risk of default and for which no mortgage lending would occur. Accordingly, homeownership and economic development was much more difficult or impossible in these redlined areas, and they tended to be located in areas at higher risk to extreme weather (i.e., floods) or even industrial accidents. Figure 2 is an example of one of these early 1940s "redlined" maps for the city of Nashville, TN, showing the areas near the river (except the immediate business district downtown) as areas where home loans could not easily be secured (Nelson et al. n.d.). Figure 3 shows this redlined area with current and possible $^{5}$ rental properties indicated, demonstrating a legacy of higher flood risk and lack of homeownership that endures to this day, with several rental properties located within the floodplains.

In addition, Moye (2014) and others have demonstrated that homes in minority neighborhoods still receive lower valuations than a similar quality/age home in a predominantly white neighborhood. Thus, even under revised programs, such as those recommended by the authors below that would provide the tenant some post-disaster relief based on the value of the home, tenants in predominantly non-white areas would receive less than similarly situated tenants in predominately white neighborhoods. Minority neighborhoods also have a history of tax assessors over assessing the minority-owned homes while under assessing white-owned homes, leading to a larger relative (percentage) tax burden for minority-owners (Rothstein 2017).

Finally, within the more vulnerable group of renters, white renters fare far better than black renters (Washington et al. 2006; Peacock et al. 2014). Washington et al. (2006) found that after Hurricane Katrina, "displaced African Americans seeking apartments have experienced housing discrimination, receiving significantly worse treatment than white apartment seekers." Their study documented examples of post-disaster white rental applicants having application and deposit fees waived, where the black applicant received no such waivers. In another study by Peacock et al. (2014), it was found that

\footnotetext{
5 Properties deemed as "possible" rental properties included those parcels with a land used designation of the following: duplex, triplex, quadplex, apartment: high rise (3 stories or greater), apartment: low rise (built since 1960), or apartment: walk up (built prior to 1960). Parcel data was obtained from the Metro Nashville Planning Department.
}

owner-occupied and housing in higher-income neighborhoods suffered less damage and recovered more quickly while housing with renters recovered more slowly and was susceptible to turnover.

In short, renters in the USA that are located in areas increasingly vulnerable to extreme weather events are more likely to be non-white, live in homes that may be less resilient to climate events, have less access to post-disaster support, and have less access to pre- or post-disaster resources to enable a permanent move away from the at-risk area in a way that does not also lower their quality of life or standard of living.

\section{Home buy-out programs and renters}

Because home buy-out programs are the most often used "managed retreat" program in the USA (Siders 2019), it is important to understand their impact on renters. The emphasis on these types of programs inherently leaves renters behindone must own a home to be eligible for the city or state to buy that home. In this section, we examine home buy-out programs and their impact on renters.

In response to major flooding on the Mississippi in 1993, congress increased funding available for permanent hazard mitigation measures across the USA, such as home buy-out programs and advance planning measures to prevent and minimize impacts after a disaster (i.e., mitigation programs) (Environmental Law Institute (ELI) 2017). Congress authorized Federal Emergency Management Agency (FEMA) to implement a number of grants, including the Hazard Mitigation Grant Program (HMGP), the Flood Mitigation Assistance Program, the Building Resilient Infrastructure and Communities (BRIC) program, and the Pre-Disaster Mitigation (PDM) Program (FEMA n.d.-a). It is these programs, in particular the HMGP, that serve as the backbone, and primary funding source, for all home buy-out programs in the USA, and their primary goal is to "reduce the number of claims paid by the [National Flood Insurance Program] NFIP" (ELI 2017).

ELI (2017) recognized that since 1993, the HMGP has prioritized home/property buy-out programs over other disaster or resilience assistance grants, accounting for nearly $40 \%$ of total grants through 2013 (ELI 2017). This prioritization of property owners entirely neglects renters. Of course, there are often substantial bureaucratic barriers to timely obtaining disaster relief for homeowners (Fazio 2014), but the homeowner at least has the possibility of some pay out, renters have none.

The home buyout process typically begins with a federal disaster declaration, which authorizes certain federal funding mechanisms that flow to states and local governments and can ultimately cover up to $75 \%$ of the total costs of a home buyout program. Local governments, in turn, take the application for a buy-out or other assistance from the property owner. In some cases, local flood program managers can proactively 


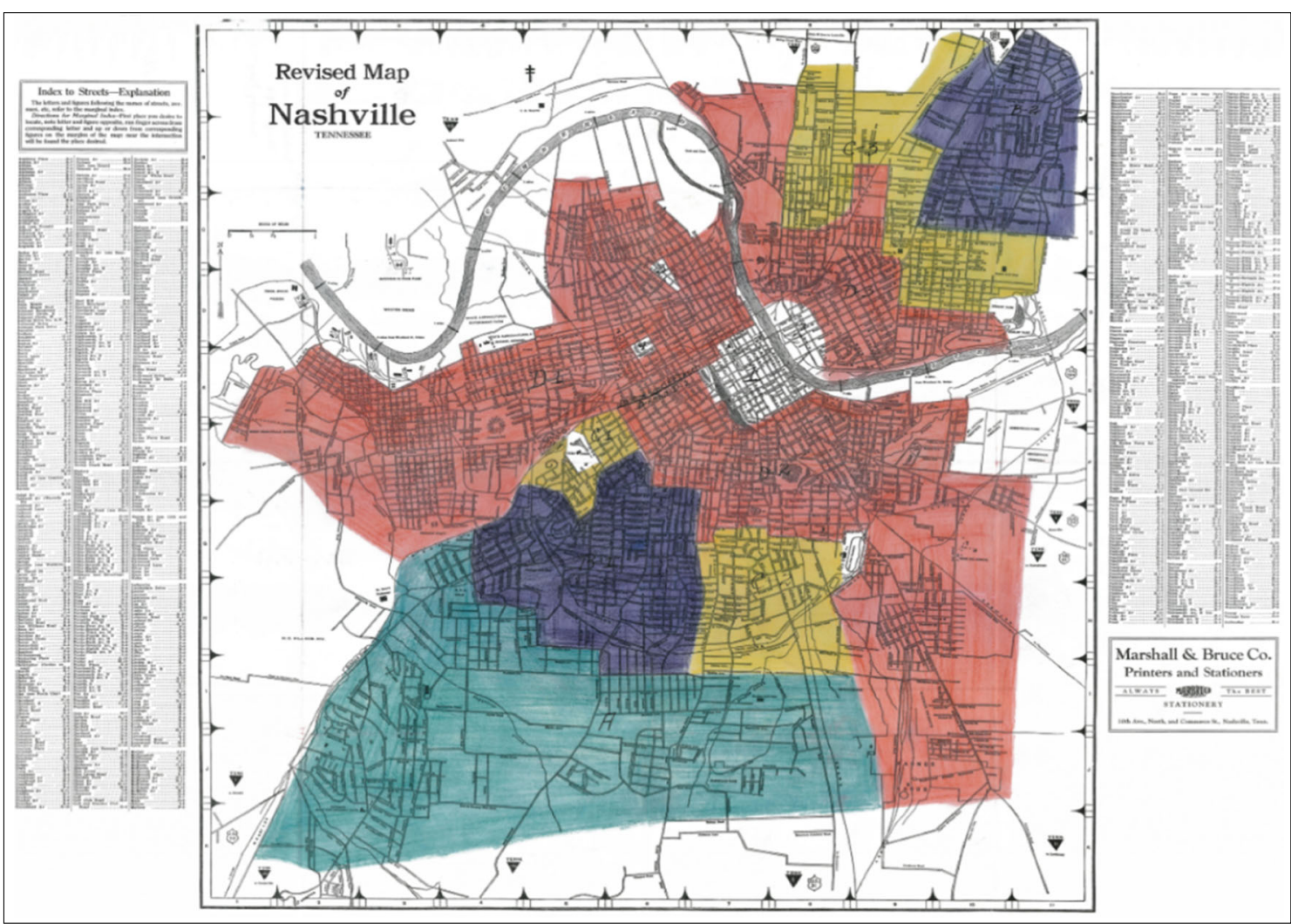

Fig. 2 Early 1940s map of Nashville with "redlining" (Nelson et al. n.d.), where home mortgages could not easily be obtained, in higher-risk areas (near the river) that were often in predominately black communities

identify properties that have experienced multiple disaster events with substantial losses (these are typical requirements for buyout). FEMA has express regulations regarding what types of expenses may be recoverable, set forth in 40 C.F.R. $\S 80.9$. These costs include money for the value of the structures, including relocation and demolition, but does not mention renters (or rental income to the owner) and expressly excludes any reimbursement for "legal obligations," including any legal obligation the landlord owes a tenant under the terms of a lease. In effect, the federal government has prioritized protection of and disaster assistance to help homeowners, but individuals that may be living in those same homes under the terms of a lease are entirely overlooked - de-prioritized - by these home buy-out programs.

FEMA is responsible for developing maps (including flood zones, floodplain boundaries, and base flood elevation) of the inland riverine flood and coastal storm surge hazard areas in the USA, but between 2014 and 2018, "more than 40 percent of flood insurance claims came from outside high-risk areas" (FEMA n.d.-b) and FEMA has been criticized for not adequately or in a timely manner updating its maps to reflect climate change data (Department of Homeland Security DHS 2017). FEMA issued preliminary revised floodmaps for some areas in December 2019. Therefore, there are

$\overline{{ }^{6} 44 \text { C.F.R. } \$ 80.9(e) ~(n . d .) . ~}$ potentially more renters and others at risk than have been identified. Many of those renters may lack information that they are at risk or the resources such as insurance through NFIP or other programs to protect themselves.

Furthermore, flood insurance (often with rates determined by the level of risk based upon the flood maps) is also an important and often overlooked factor for renters. Most renters' insurance does not include events like flooding (unless an additional flood insurance policy is purchased) and the property owner's insurance does not cover any of the renters' property nor temporary relocation (Sachon 2018). Insurance often provides a means for the property owner to rebuild and recover, but no such benefits are transferred to the renter. The Flood Mitigation Assistance Program can provide funds to reduce the risk of flood damage, but the property must be insured pursuant to the NFIP. Lack of NFIP insurance, in some cases, could mean that the property does not qualify for buy-out even if it has flooded multiple times. Lack of NFIP insurance also means that there may not be available records or information of prior flooding for a property, making it more difficult for a renter to determine such risk. If a renter is not aware of whether the rental property has flood insurance, is in a high-risk flood zone, or whether it has flooded before (as noted, typical requirements for a home buy-out program (Adler et al. 2019)), this places the renter at a disadvantage before he/she even enters the lease. 


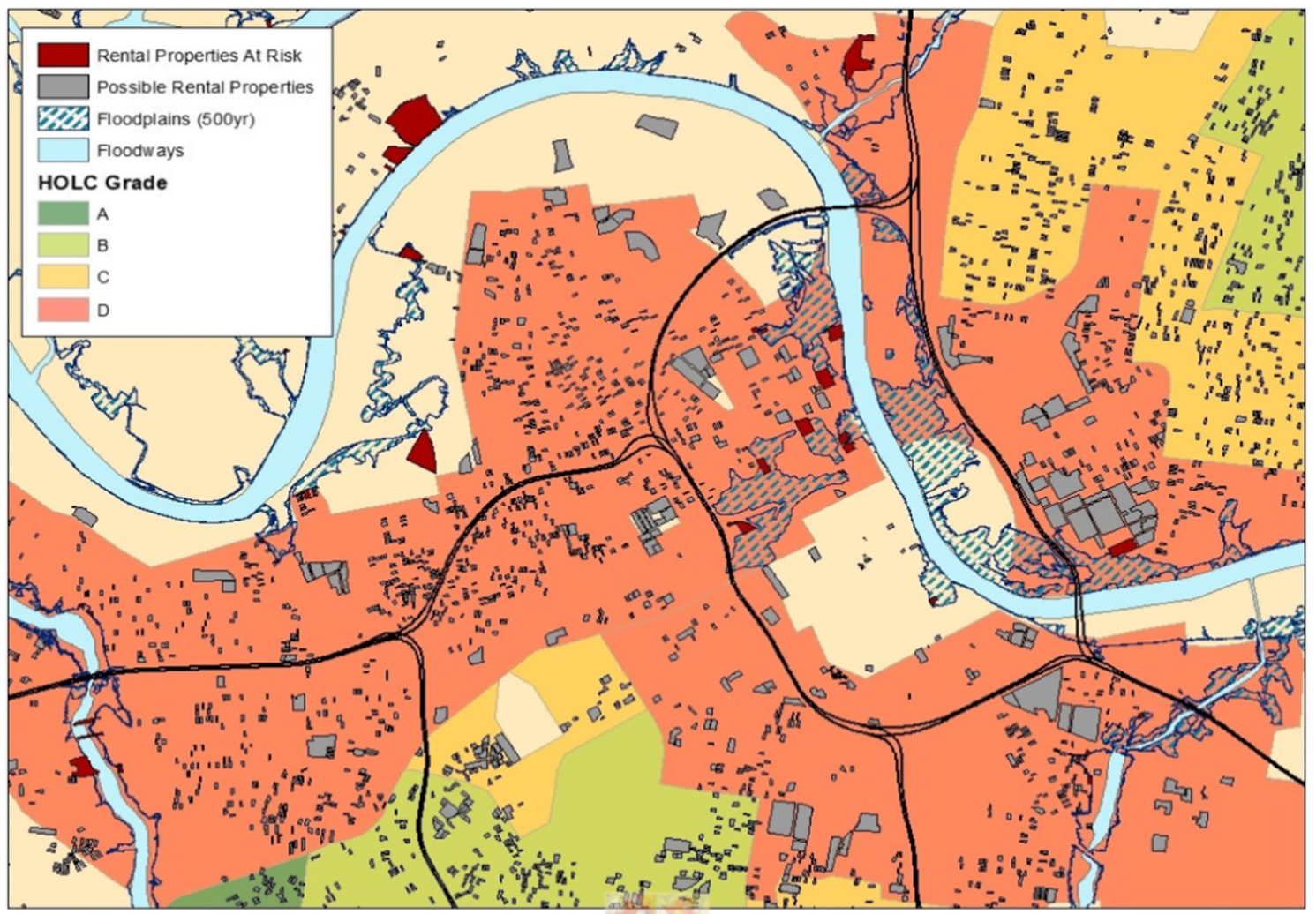

Fig. 3 "Redlined" areas from early 1940s maps with high-risk flood zones and current rental properties identified. The 1933 Home Owners' Loan Corporation (HOLC) color-coded map areas based on risk for mortgage lending, often identifying black neighborhoods in "red" (high risk) and making it difficult for homeownership to occur in those areas. Current rental properties are indicated in relation to the old redlined areas. Flood plains are indicated as hatched areas

rent, or even become homeless, thus increasing their economic hardship. Ironically, protecting oneself with renters' insurance may disqualify a renter from eligibility for any postdisaster FEMA assistance that would otherwise be available (Von Kaenel 2020). Journalists examining the plight of renters after the Camp fire in California noted that renters were faring worse; even if pre-disaster, they had similar incomes and living standards. "It's really the fire that is turning renters into poor people" (Von Kaenel 2020).

The impacts of a reduction in affordable housing stock after a disaster (whether from physical destruction of the property or from a buy-out program) have been seen in the aftermath of both Hurricanes Katrina and Harvey (Associated Press (AP) 2006; Sastry 2009). There is currently a shortage of affordable rental housing in the USA according to the National Low Income Housing Coalition as indicated by Fig. 4 below. No state in the USA has enough affordable rentals for the demand. In some states, there are less than $1 / 3$ of the rental properties available than are needed, especially in high-risk states. This situation is only exacerbated by the impacts to housing stock and prices in local areas following a disaster.

Given these circumstances, renters are at a multi-pronged disadvantage. Contributing further to this disadvantage is the fact that property owners reliant on rental income, such as 
Fig. 4 Available and affordable rental housing for low-income renters expressed as the number of properties available per 100 lowest-income renters. (Source: National Low Income Housing Coalition (NLIHC 2020))

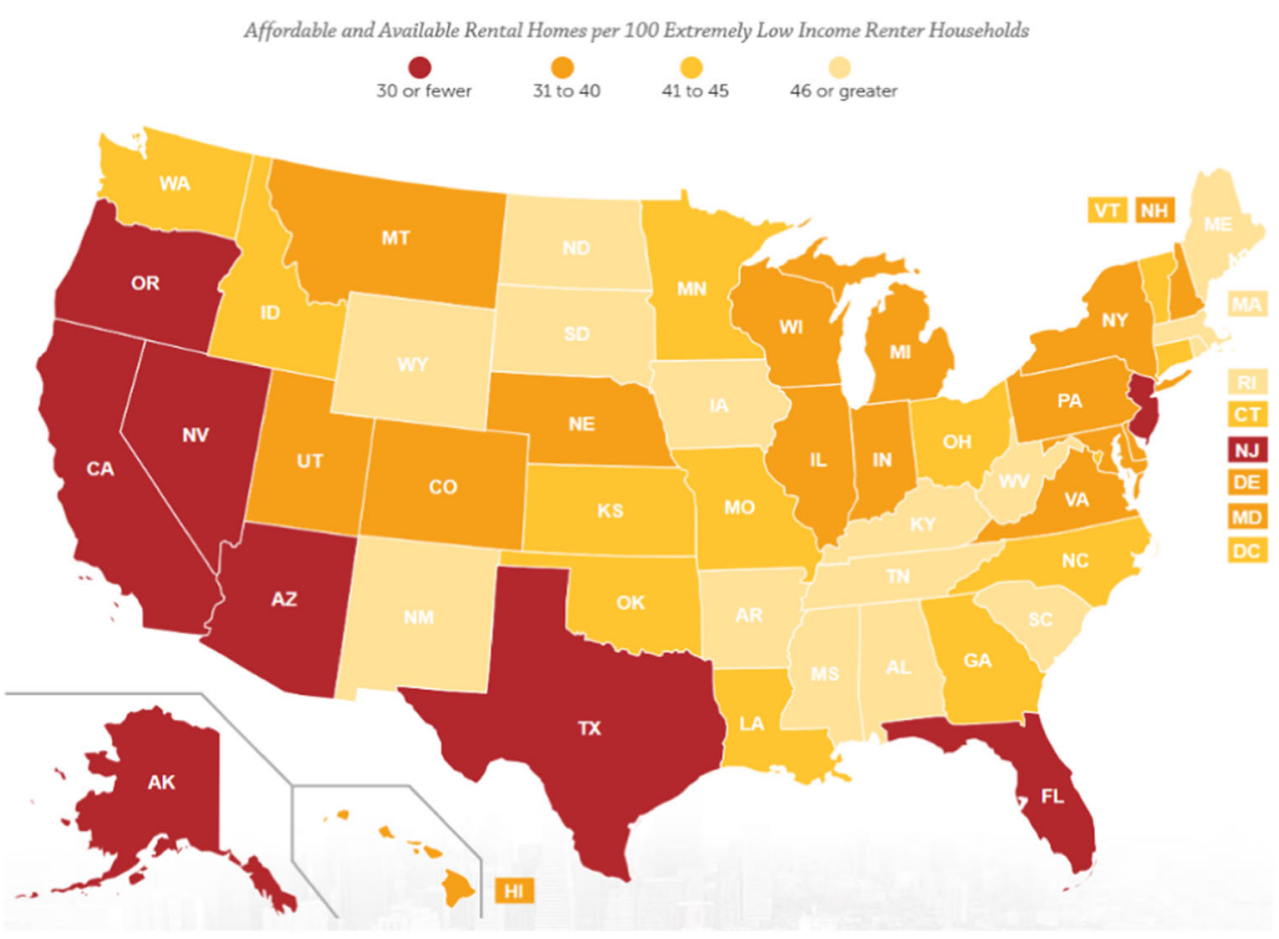

those with multi-family units, may be incentivized to decline the buy-out options. They then re-build or repair in the same (potentially increasingly) risky location, continuing to put renters at risk, often without their knowledge. The situation can become additionally complicated when the multi-unit dwelling is owneroccupied or has more than a few units. The cap on NFIP payouts can be inadequate for larger multi-unit dwellings and private flood insurance may be necessary to fully cover the repairs. Also, in an effort to optimize risk reduction, local flood managers with limited funds may prioritize multiple single-family homes that may be more affordable than higher-valued multi-family units. Renters who are aware of the risks may have access to flood insurance (FEMA 2020b), but the cost of that insurance is increased by factors over which a tenant has no control, such as the age of the building, the flood zone, and other measures owners can take to reduce flood risk. Current policies often do not provide incentives to landlords to address any of those factors that might make flood insurance more affordable for the tenant. To qualify for flood insurance, the property also must be located in a community covered by the NFIP (FEMA 2020a). If obtainable, however, such a policy would cover household belongings and could substantially assist the tenant in the event of a disaster.

\section{Recommendations}

The NFIP and FEMA programs have faced much scrutiny in the past two decades as US residents have dealt with more billion-dollar disasters and have begun realizing the inadequacies of available programs and policies. As noted earlier, these programs are predominantly focused on offering assistance and relief to homeowners, and renters are predominantly left out. However, as noted by Paine (2017) and others, the majority of individuals at risk in the floodplains of the USA are renters, and predominantly non-white. Many at-risk individuals and families are excluded from the safety net that these programs are set up to provide.

The authors recognize the complexity and gravity involved with changing an entrenched system, but there are some actions that can be taken to assist those most in need and most at risk. Based on the authors' research, knowledge, and discussions with FEMA officials and local floodplain managers, the following recommendations could be considered in addressing the increasing impact of climate change on the vulnerable rental population.

1. Improve education and outreach to renter communities about risks and insurance.

a. Local floodplain managers can work with their tax officials to identify potential rental properties in the floodplains for a targeted flood risk education outreach effort. This could be done in partnership with local NGOs when local government is limited in staffing and funding for such efforts. Working with NGOs and community or cultural leaders can also help to overcome the concerns for immigrants who may not be legally documented or who face language barriers and might otherwise not interact with government officials. 
b. Communities that participate in the NFIP Community Rating System (CRS) (FEMA 2017) are considered to be exceeding the federal floodplain management standards. For CRS communities, an outreach effort such as a door-knocking campaign to identify and inform renters about the risks and flood insurance could be awarded in the CRS points system, and would help get the needed information in the hands of those that need it most. A robust outreach effort targeting renters may result in fewer community residents needing assistance following an event as well as potentially lowering flood insurance premiums across the entire community.

iii. FEMA and local floodplain officials can improve the ease of access to and availability of easily understandable information. Requiring renters to proactively investigate to understand flood risks and prior flooding at the property through due diligence, data exploration, and the FEMA website is proving insufficient. As one example, the authors learned from a floodplain manager (an individual with sophisticated knowledge of flood impacts and managing recovery funding) that the individual did not personally know without some investigation whether relocation costs or temporary housing for renters is covered by flood insurance.

2. Eligible communities not currently in the NFIP CRS should apply and become part of the CRS to reduce flood insurance premiums for residents (both homeowners and renters). Although homeowners may be more directly impacted because owners are more likely to hold the flood insurance policy that receives a CRS program premium discount, renters can benefit in several ways, even if they do not hold flood insurance directly. The CRS rating system incentivizes protection of natural and floodplain barriers, better community education around flood risks, and improved public warning systems. These and other measures impact and benefit the entire community, including renters, and can reduce flood risks for renters and owners alike. There are 19 creditable activities in four categories: public information, mapping and regulations, flood damage reduction, warning, and response (FEMA 2017).

3. Local or state governments could consider and create a means of enforcement to require landlords to notify tenants of flood risks and prior flooding history of the property. As seen in the Willow River apartment situation in Virginia, many tenants have no idea that they are moving into an at-risk situation. More research is needed, but requiring notifications to tenants in at-risk areas may have the following outcomes:

a. Tenants are more risk aware and can make a betterinformed decision about the need for rental and/or flood insurance. b. A legal requirement of risk notification may in turn incentivize landlords to require tenants to obtain insurance (potential rent reduction could be used in exchange to offset insurance premiums) or to themselves invest in property upgrades to increase resilience.

c. Notice may increase knowledge that both landlord and tenant can use to potentially negotiate lease terms to protect the tenant in the event of a disaster (e.g., should a flood occur, the landlord will use a certain agreed upon amount of FEMA or property insurance recovery to cover the costs of temporary housing for the tenant until repairs can be made).

d. A notice requirement may de-incentivize property owners from keeping the property after a flood event, knowing the risks and potential loss of income if the risks are disclosed.

4. Examine FEMA, NFIP, and State insurance and landlord/ tenant laws and regulations for appropriate areas for modifications that could increase the availability and utilization of renter disaster insurance (i.e., flood or earthquake) for hazards not typically covered by general rental insurance policies. Some potential approaches:

a. For renters in floodplains, consider whether lease agreements should require the renter to obtain flood insurance. The national average premium for renter's insurance is about $\$ 180$ per year (Insurance Information Institute 2020). Flood insurance can have similar premiums. If such flood insurance is required, there should be appropriate notice provisions and clear understandings regarding who owns the policy, for whose benefit, whether the premium payments are included in the cost of the rent, and what is covered. For example, if the landlord maintains the policy for the benefit of the renter, and the cost is included in the rent, such a policy may not cover the tenant's belongings.

b. Reflect the property location and risks (e.g., risk of flooding) in the price of renter's insurance policy. In this way, the market price of the rent may reflect the increased cost of the insurance policy that the renter must pay in addition to the rent. In short, a landlord may not be able to rent a property for as high a price if it is located in a floodplain and the cost of rental insurance is high.

iii. Consider subsidies to offset the costs of flood insurance premiums for renters. For example, subsidies could come from local or state governments, or NGOs and other civic groups that work with low-income residents.

iv. Increase knowledge and understanding by local authorities of the opportunities for assistance to renters 
associated with buy-outs or other federally funded flood mitigation programs, such as assistance with relocation costs.

5. Develop FEMA regulations that would incentivize landlords that use home buy-out programs to provide some measure of relief for existing tenants. Buy-out programs typically pay the fair market value of property prior to the disaster event. This does not account for the loss of income for landlords, or the lost home/possessions for the renter. Potential options include:

a. 1-2 years of rental income for the landlord (or set the length using a formula that takes account of the frequency of historic flooding to the property, with less payout for more frequent flooding events) based upon current area average rates for similar amenities or rental amount at the time of the disaster. While this would be a large up-front cost to the buy-out program (which is typically predominantly federal dollars), it would reduce future personal assistance (for both the landlord and tenant(s)) and insurance pay outs for the property. As noted by the Pew Charitable Trusts (2016), approximately $1 \%$ of properties account for "more than a quarter of NFIP claims." This would reduce future repetitive loss payouts and potentially save taxpayer dollars over time.

b. Create a requirement that a percentage (e.g., 5-10\%) of the buy-out go to the renter(s) to help cover their losses and the burden of being displaced (even if it is temporary). This could be determined based upon valuation of the property and the documented monthly rent (or average rent for the area). This is most important in disaster situations that do not result in a presidentially declared disaster where there may be no coverage or reimbursement for temporary housing. Such a requirement would provide some relief to the tenant (in the absence of NFIP provisions to appropriately provide rental assistance) and also potentially de-incentivize the landlord from continuing to own and operate the property in a high-risk area.

The potential solutions and strategies for addressing the climate justice implications for renters are only just beginning to be explored. Robust and targeted research is needed to understand and address these problems, and to prompt needed conversations.

\section{Conclusion}

Although there are federal disaster relief programs aimed at permanently removing high-risk properties from an area such as home buy-out programs (which also serve as the primary form of managed retreat in the USA), those programs tend to prioritize and benefit property owners for the most part. In the USA, because of the long history of racially -driven marginalization policies and practices, renters are more likely to be minorities and low-income populations. These same factors have also led, in many areas, to limited, affordable rental housing stock being located in higherrisk areas. The plight of renters within the context of climate justice considerations is one that cannot be overlooked, especially considering the prevalence of renters in floodplains. As climate change creates more severe disasters and our population increases, the situation is likely to worsen.

Under these considerations, the authors have coined the term Renters' Climate Inequities (RCI) to encompass the collection of undue, coupled burdens, and challenges faced by renters at risk of natural hazards. In this paper, we have enumerated seven such inequities. This is by no means an exhaustive list, but instead the first attempt to document and describe the challenges of this vulnerable population.

The authors set forth the above recommendations for policies and additional research that will continue to shine a spotlight on this historically overlooked group. Including how managed retreat programs, in particular home buy-out programs, might be revised to include this increasingly vulnerable population in light of a changing climate.

The authors note that COVID-19 has compounded many of the problems discussed in this paper faced by renters. Those renters that were dependent on employment in sectors especially hard hit by the pandemic, such as hospitality and tourism, have had to face the inability to pay rent, and in many parts of the country, at the same time as wildfires or hurricanes or flooding.

Acknowledgements The authors would like to thank and acknowledge Mitch Paine with the Federal Emergency Management Administration, Roger Lindsey and Tom Palko of Nashville's Metro Water Services and staff at the Metro Nashville Planning Department, Kelsey Oesmann with Nashville's Urban Housing Solutions, Nick Scatterfield with the Community Adaptation Program of the New Orleans Redevelopment Authority, Velma Smith of the Pew Charitable Trusts, Marla Nelson at the University of New Orleans, and the many others that have helped seed the ideas for this paper over the years through ASFPM and other conferences. Their insight was invaluable and provided important perspective on this under-researched topic.

Data availability The data and material utilized in this manuscript is in the public domain or is available upon request.

\section{Declarations}

Conflict of interest The authors declare no competing interests.

\section{References}

12 U.S.C. § 1701, et seq n.d. National Housing Act. U.S. Code 38 U.S.C. $\S 3701$ et seq n.d. (current provisions) U.S. Code 
44 C.F.R. $\$ 80.9($ e). n.d. U.S. Code of Federal Regulations

Adler D, Burger M, Moore R, Scata J (2019) Changing the National Flood Insurance Program for A Changing Climate. Environ Law Report News Anal 49(4):10320

Ahmed A (2019) How the government fails low-income renters after natural disasters. Southerly Magazine, November 14, 2019. https:// southerlymag.org/2019/11/14/how-the-government-fails-lowincome-renters-after-natural-disasters/. Accessed 30 Apr 2021

AP (2006) Low-income Katrina victims face eviction. April 18, 2006. Associated Press http://www.nbcnews.com/id/12375321/ns/us news-katrina the long_road_back/t/low-income-katrina-victimsface-eviction/\#.X15-zItOmUk Accessed 2 September 2020

Blakemore E (2019) How the GI Bill's promise was denied to a million Black WWII veterans. History Stories. https://www.history.com/ news/gi-bill-black-wwii-veterans-benefits Accessed 29 August 2020

Burby R et al (2003) The tenure trap: the vulnerability of renters to joint natural and technological disasters. Urban Aff Rev 29:32

DHS (2017) FEMA needs to improve management of its flood mapping programs. U.S. Department of Homeland Security Office of Inspector General OID-17-110. September 27, 2017 https://www. oig.dhs.gov/sites/default/files/assets/2017/OIG-17-110-Sep17.pdf Accessed 28 August 2020

Environmnetal Law Institute (ELI) (2017) Floodplain buyouts: an action guide for local governments on how to maximize community benefits, habitat connectivity, and resilience. Environmental Law Institute, University of North Carolina, Institute for the Environment, pp 1-77

Fazio C (2014) Ensuring equitable disaster relief to homeowners and business impacted by natural disasters. Fordham Environ Law Rev 26(1) https://ir.lawnet.fordham.edu/elr/vol26/iss1/2 Accessed 15 September 2020

FEMA (2017) Community Rating System (CRS) fact sheet. U.S. Federal Emergency Management Agency (FEMA) http://www.fbfl.us/ DocumentCenter/View/17848/NFIP_CRS_Fact_Sheet_2017_ 508OK?bidId= Accessed 10 September 2020

FEMA (2019) FEMA Hazard Mitigation Assistance Sever Repetitive Loss (SRL) Data. https://catalog.data.gov/dataset/fema-hazardmitigation-assistance-severe-repetitive-loss-srl-data. Accessed 29 January 2021.

FEMA (2020a) Community status book. U.S. Federal Emergency Management Agency (FEMA) https:/www.fema.gov/floodinsurance/work-with-nfip/community-status-book Accessed 11 September 2020

FEMA (2020b) Types of flood insurance, renter. U.S. Federal Emergency Management Agency (FEMA) https://www.floodsmart.gov/floodinsurance/types Accessed 11 September 2020

FEMA (n.d.-a Available Grants - FEMA Administered. U.S. Federal Emergency Management Agency (FEMA) https://www.fema.gov/ grants/mitigation Accessed on 9 September 2020

FEMA (n.d.-b Flood map info sheet. U.S. Federal Emergency Management Agency (FEMA) https://www.floodsmart.gov/floodmap-zone/about Accessed 27 August 2020

FEMA (n.d.-c National Flood Insurance Program - what flood insurance covers. U.S. Federal Emergency Management Agency (FEMA) https://www.floodsmart.gov/flood-insurance/coverage Accessed 6 September 2020

FEMA (n.d.-d Property acquisitions for open space - frequently asked questions. U.S. Federal Emergency Management Agency (FEMA) https://www.fema.gov/media-library-data/1487973067729d34bd451527229a45bad0ef5ac6ddf93/508_FIMA_Acq_FAQs_2 24_17_Final.pdf Accessed 27 August 2020

Fussell E (2015) The long term recovery of New Orleans' population after Hurricane Katrina. Am Behav Sci 59(10):1231-1245
Fussell E, Sastry N, VanLandingham M (2010) Race, socioeconomic status, and return migration to New Orleans after Hurricane Katrina. Popul Environ 31(1-3):20-42

Hammack L (2019) Federal insurance rebuilds Salem apartments despite floods. The Roanoke Times. May 20, 2006, Updated Jun 6, 2019. https://roanoke.com/webmin/news/federal-insurance-rebuildssalem-apartments-despite-floods/article_41d52605-fadd-5cc3a424-0f2fabb8dfef.html

Insurance Information Institute (2020) Facts + Statistics: Homeowners and renters insurance. https://www.iii.org/fact-statistic/factsstatistics-homeowners-and-renters-insurance. Accessed 6 Sept 2020

Kochhar R, Fry R, Taylor P (2011) Twenty-to-one: wealth gaps rise to record highs between Whites, African Americans and Hispanics. Pew Research Center https://www.pewresearch.org/wp-content/ uploads/sites/3/2011/07/SDT-Wealth-Report 7-26-11_FINAL.pdf Accessed 25 August 2020

Mach KJ et al (2019) Managed retreat through voluntary buyouts of flood-prone properties. Sci Adv 5:10. https://doi.org/10.1126/ sciadv.aax 899

MDC (n.d.) When disaster strikes: disaster planning and best practices for socially vulnerable populations, Promising Practices - Renters https://www.mdcincorg/when-disaster-strikes/ Accessed 1 September 2020

Miller K (2017) Renters' Rights Dealing with Flood Damage in Texas. RENTEC DIRECT, https://www.rentecdirect.com/blog/flooddamage-renters/. Accessed 31 January 2021

Moye R (2014) Neighborhood racial-ethnic change and home value appreciation: evidence from Philadelphia. Urban Geogr 35(2):236 263

Murray M (2008) When war is work: the G.I. bill, citizenship, and the civic generation. Calif Law Rev 96:967-972

Nelson KS, Camp JS (2020) Quantifying the benefits of home buyouts for flood mitigation. Anthropocene 31:100246. https://doi.org/10. 1016/j.ancene. 2020.100246

Nelson R et al (n.d.) Mapping inequality. American Panorama ed. RK Nelson and EL Ayers. https://dsl.richmond.edu/panorama/redlining Accessed 10 September 2020

NLIHC (2020) The gap: a shortage of affordable rental homes. https:// www.reportsnlihcorg/gap Accessed 12 September 2020

Paine M (2017) Who lives in floodplains? Research \& strategies to keep everyone safe. ASFPM National Conference, Kansas City, Missouri, Thursday, May 4, 2017

Paine M (2019) Equity and social justice: what King County is doing to manage floodplains more equitably. ASFPM National Conference, Raleigh, NC, May 21, 2019

Peacock WG, Van Zandt S, Zhang Y, Highfield WE (2014) Inequities in long-term housing recovery after disasters. J Am Plan Assoc 80: 356-371

Pew Charitable Trusts (2016) Repeatedly flooded properties cost billions: new policies are needed to break a cycle of loss and rebuilding. An infographic from the Pew Charitable Trusts. October 2016. https:// www.pewtrusts.org/ /media/assets/2016/10/repeatedly_flooded properties_cost_billions.pdf?la=en Accessed on 10 September 2020

Ramos H (1998) The American G.I. Forum. In: Pursuit of the Dream, 1948-1983. Arte Publico Press, Houston, TX

Rice J (2019) Texas lawmakers gave more flood risk disclosure protection to home buyers, but not renters Houston Public Media https:// www.houstonpublicmediaorg/articles/news/2019/05/31/335237/ texas-lawmakers-gave-more-flood-risk-disclosure-protection-tohome-buyers-but-not-renters/ Accessed 29 January 2021.

Rothstein R (2017) The color of law. Liveright Publishing Corporation, New York

Sachon L (2018) What renters need to know about flood insurance. Policygenius.com https://www.policygenius.com/rentersinsurance/what-renters-need-to-know-about-flood-insurance/ Accessed 11 September 2020 
Sastry N (2009) Tracing the effects of Hurricane Katrina on the population of New Orleans: the displaced New Orleans residents pilot study. Sociol Methods Res 38(1):171-196

Siders AR (2019) Perspective: managed retreat in the United States. One Earth 1:216-225. https://doi.org/10.1016/j.oneear.2019.09.008

SRL (2013) Tenants: an overlooked vulnerable population in disaster research and recovery. Superstorm Research Lab https:// superstormresearchlab.org/2013/10/23/tenants-an-overlookedvulnerable-population-in-disaster-research-and-recovery/ Accessed 20 August 2020

Tex. Rev. Civ. Stat. Ann n.d. § 92.058, Property Code

Traub A et al (2015) The racial wealth gap: why policy matters. Demos.org and Institute for Assets \& Social Policy, Brandeis University pp. 40

Tutt A (2013) On the invalidation of terms in contracts of adhesion. Yale J Regul 30:439-474

Uniform Relocation Assistance and Real Property Acquisition Policies for Federal and Federally Assisted Programs Act of 1970, 42 U.S.C $\S 4601$ et seq.

US Census Bureau (2018) 2017 American Housing Survey - data and table creator. https://www.censusgov/programs-surveys/ahs/data/ interactive/ahstablecreatorhtml?s_areas $=00000 \&$ s_year $=2017 \&$ s tablename $=$ TABLES $06 \& \mathrm{~s}$ bygroup $1=1 \& \mathrm{~s}$ bygroup $2=1 \& \mathrm{~s}$ filtergroup $1=3 \&$ s_filtergroup $\overline{2}=1$ Accessed 12 September 2020

US HUD (2018) HUD Community Block Grant-Disaster Recovery (CDBG-DR), State of Texas Allocation. 46 No. CD-15 HDR,
Current Developments NL 6. U.S. Department of Housing and Urban Development

USGCRP (2018) Fourth National Climate Assessment, Volume II: impacts, risks, and adaptation in the United States. Reidmiller DR, Avery CW, Easterling DR, Kunkel KE, Lewis KLM, Maycock TK, Stewart BC (eds) U.S. Global Change Research Program, Washington, DC, USA, pp. 1515 pp. doi: https://doi.org/10.7930/ NCA4.201

Von Kaenel C (2020) Renters falling through the cracks of disaster recovery. Chico Enterprise-Record https://www.chicoercom/2020/03/ $12 /$ renters-falling-through-the-cracks-of-disaster-recovery/ Accessed 15 September 2020.

Washington T, Smedley BD, Alvarez B, Reece J (2006) The State of Housing in New Orleans one year after Katrina: policy recommendations for equitable rebuilding. NAACP Reports http://www. kirwaninstitute.osu.edu/reports/2006/08_2006_HousingNOLA_ KI_OppAg_NAACP.pdf

Weil J (2009) Finding housing: discrimination and exploitation of Latinos in the post-Katrina rental market. Organ Environ 22(4):491-502 Retrieved September 15, 2020, from http://www.jstor.org/stable/ 26162050

Publisher's note Springer Nature remains neutral with regard to jurisdictional claims in published maps and institutional affiliations. 